\title{
Overview of recommended blood transfusion therapy in thalassaemia major
}

John Porter

Red Cell Disorders Unit, University College London Hospitals and UCL, London, UK

\section{Oral presentation}

Oral presentation is available online

\author{
Correspondence: John Porter \\ E-mail: j.porter@ucl.ac.uk \\ (C) Copyright J. Porter, 2013 \\ Licensee PAGEPress, Italy \\ Thalassemia Reports 2013; 3(s1):e22 \\ doi:10.4081/thal.2013.s1.e22 \\ This article is distributed under the terms of the Creative Commons \\ Attribution Noncommercial License (by-nc 3.0) which permits any noncom- \\ mercial use, distribution, and reproduction in any medium, provided the orig- \\ inal author(s) and source are credited. \\ Parts of this work were presented at the \\ "3rd Pan-European Conference on Haemoglobinopathies and Rare Anaemias", \\ Limassol (Cyprus), 24-26 October 2012.
}

